https://ejournal.uniska-kediri.ac.id/index.php/Diversi

P-ISSN: 2503 - 4804, E-ISSN: 2614 - 5936, DOI: 10.32503

\title{
LEMBAGA PENYELESAIAN SENGKETA PEMILU YANG IDEAL DI INDONESIA
}

\author{
R. Fauzi Zuhri Pradika. ${ }^{1}$ Happy Anugraha Sutrisno Putra. ${ }^{2}$ Anwar Noris. ${ }^{3}$ \\ Fakultas Hukum Universitas Airlangga \\ Jl. Dharmawangsa Dalam Selatan, Airlangga, Kec. Gubeng, Kota Surabaya, \\ Jawa Timur, Indonesia \\ Email: dikakriwul@gmail.com
}

\begin{abstract}
This article discussed the legal statements about Election Supervisory Board as Special Court. Over the years, the dispute on the result of vote counting is decided by Constitutional Court which the main function is to examine the statute against the Indonesian Constitution year 1945. Therefore, it is required to establish an independent and final agency to handle the general election dispute. The purpose of this study is to reform a law system in Indonesia. The research used is legal research due to no legal rule for the problem issued. It is also applied Statute Approach, Conseptual Approach, Case Approach, and Law Material Source from Primary and Secondary law material. The dispute on election was decided by Constitutional Court. Meanwhile, the primary function of it is reviewing the statute against the Indonesian Constitution year 1945. Based on the result study, the establishment of Special Court to replace the Constitutional Court considered to be essential. The Election Supervisory Agency as an independent agency that controlled the general election could be the special court agency to handle an election dispute. As for Brazil and Thailand has developed superior electoral court to resolve an election dispute.
\end{abstract}

Keywords: Election Supervisory Board, Special Court, general election.

\begin{abstract}
ABSTRAK
Artikel ini berisi tentang pendapat hukum tentang Badan Pengawas Pemilihan Umum Sebagai Badan Peradilan Khusus yang mana sampai sekarang, sengketa hasil pemungutan suara masih diselesaikan oleh Mahkamah Konstitusi yang mana tugas inti atau pokok dari Mahkamah Konstitusi adalah menguji undang-undang terhadap Undang-Undang Dasar Republik Indonesia tahun 1945. Sehingga perlu adanya Lembaga yang menangani sengketa pemilu bersifat independen dan final. Tujuan Penelitian ini adalah untuk pembaharuan sistem hukum di Indonesia. Penelitian yang digunakan adalah penelitian hukum (legal research) dilakukan karena memang belum ada aturan hukum untuk masalah yang dihadapi. Serta menggunakan Pendekatan Undang-Undang (Statute Approach), Pendekatan Konseptual (Conseptual Approach), Pendekatan Kasus (Case Approach) dan Sumber Bahan Hukum yang digunakan Bahan Hukum Primer dan Sekunder. Hasil penilitian ini menjelaskan bahwa selama ini sengketa pemilu diputus oleh Mahkamah Konstitusi. Sedangkan fungsi Mahkamah Konstitusi yang utama adalah menguji undang-undang terhadap Undang-Undang Dasar Republik Indonesia tahun 1945. Sehingga perlunya Lembaga peradilan khusus untuk menggantikan Mahkamah Konstitusi. Badan Pengawas Pemilihan Umum sebagai lembaga independen yang berfungsi sebagai pengawas pemilu ini bisa dijadikan sebagai lembaga peradilan khusus untuk menangani sengketa pemilu. Seperti halnya negara Brazil dan Thailand yang menggunakan superior electoral court untuk menyelesaikan sengketa pemilu.
\end{abstract}

Kata Kunci: Badan Pengawas Pemilihan Umum, Badan Peradilan Khusus, Pemilihan Umum.

${ }^{1}$ Submission: 22 Januari 2020 I Review-1: 26 Maret 2020 I Review-2: 7 April 2020 I Production: 11 April 2020 


\section{Pendahuluan}

Pemilu merupakan salah satu usaha untuk mempengaruhi rakyat secara persuasif (tidak memaksa) dengan melakukan kegiatan retorika, hubungan publik, komunikasi massa, lobi dan kegiatannya. Meskipun agitasi dan propaganda di negara demokrasi sangat dikecam, namun dalam kampanye pemilihan umum, teknik agitasi dan teknik propaganda banyak juga dipakai oleh para kandidat atau politikus sebagai komunikator politik. Indonesia telah melaksanakan beberapa kali Pemilu, dimulai sejak tahun 1955, 1971, 19771997, 1999, 2004, 2009, 2014, dan 2019. ${ }^{2}$

Proses pilkada dapat menjadi salah satu sarana integrasi bangsa untuk membiarkan masyarakat memilih sendiri kualitas pemimpin yang diinginkan. Ia adalah sistem untuk mengejewantahkan pemimpin idaman yang berasal dari masyarakat itu sendiri. ${ }^{3}$ Lembaga negara yang menyelenggarakan pemilu adalah Komisi Pemilihan Umum (bisa disebut dengan KPU) yang didirikan pada tahun 1999, sedangkan lembaga penyelenggara pemilu yang bertugas untuk mengawasi penyelenggaran pemilu di seluruh Indonesia Adalah Badan Pengawas Pemilu (bisa disebut dengan BAWASLU). Dalam menjalankan tugasnya kedua Lembaga tersebut diatur dalam Undang-Undang Nomor 7 tahun 2017 tentang Penyelenggaraan Pemilihan Umum.

Perselisihan dalam pemilu merupakan salah satu dari beberapa masalah yang akan muncul dalam penyelenggaraan pemilu. Pada Tahun 2019 Mahkamah Konstitusi (bisa disebut dengan MK) menerima 470 sengketa perkara Permohonan Hasil Pemilihan Umum (selanjutnya disingkat PHPU) pada Pemilu 2019. Secara rinci, 215 permohonan PHPU diajukan di tingkat Pemilihan Legislatif (Pileg) DPRD Kabupaten/Kota, 110 di tingkat DPRD

\footnotetext{
KPU DIY, "Sejarah Pemilu Di Indonesia," dalam https://diy.kpu.go.id/web/2016/12/22/sejarah-pemilu-di-indonesia/, Akses 23 November 2018.

3 Kariaman Sinaga, Efektitas Regulasi Dan Perannya Dalam Penyelenggaraan Pemilukada: Dialektika Hukum Dan Etika Pemilukada Serentak (Jakarta: Dewan Kehormatan Penyelenggara Pemilu RI, 2016), Hlm. 142-143.
} 
Provinsi, 71 di tingkat DPR, 11 di tingkat DPD, dan satu di tingkat Pilpres. Ada 62 permohonan PHPU yang tidak teridentifikasi tingkatan pemilunya. ${ }^{4}$

Pada tahun 2014 MK menerima 767 sengketa pemilu legislatif. 735 perkara diajukan oleh partai politik dan 32 perkara diajukan oleh calon anggota Dewan Perwakilan Daerah. ${ }^{5}$ Berdasarkan jumlah tersebut apabila dibandingkan dengan kewenangan utama MK untuk yaitu menguji konstitusionalitas Undang-Undang, maka dapat dikatakan bahwa kewenangan MK memutus perselisihan hasil pemilu jauh lebih sering dimohonkan. Sejauh ini perkara pengujian Undang-Undang terhadap Undang-Undang Dasar Tahun 1945 yang dimohonkan kepada MK berjumlah 1523 perkara sejak berdirinya dari tahun 2003-2019. Sehingga terjadi suatu pergeseran fungsi, dimana kini kewenangan utama yang dimiliki oleh MK adalah memutus perselisihan hasil pemilu bukan menguji konstitusionalitas Undang-Undang, karena meskipun pemilu itu sendiri hanya dilaksanakan 5 tahun sekali, namun jumlah perkara perselisihan hasil pemilu yang dimohonkan jauh lebih banyak dibandingkan perkara yang termasuk dalam kewenangan MK lainnya.

Selama ini, lembaga yang diberi kewenangan untuk menangani sengketa Pemilukada masih belum dijelaskan secara eksplisit. Lembaga peradilan mana yang memiliki kewenangan permanen untuk mengadili sengketa perselisihan hasil Pemilukada walau selama ini kewenangan tersebut dilaksanakan oleh MK, namun MK juga pernah memutus untuk melepas kewenangan mengadili sengketa pemilukada sebagai bagian dari kewenangannya hingga dalam Undang-Undang Nomor 1 Tahun 2015 tentang Penetapan Perppu Nomor 1 Tahun 2014 tentang Pemilihan Gubernur, Bupati, Walikota kewenagan tersebut diserahkan kepada badan peradilan Khusus.

4 Dimas Jarot Bayu, “Jumlah Gugatan Sengketa Pemilu Tahun 2019 Turun 2 Kali Lipat Dibanding 2014 dalam https://katadata.co.id/berita/2019/05/26/jumlah-gugatan-sengketa-pemilu2019-turun-2-kali-lipat-dibanding-2014, Akses 27 Desember 2019.

5 Febrian, "MK Terima 767 Sengketa Pemilu Legislatif 2014," dalam https://nasional.kompas.com/ |read/2014/05/16/1644242/MK.Terima.767.Sengketa.Pemilu.Legislatif.2014, Akses 23 November 2018. 
Berdasarkan uraian di atas dapat dikatakan bahwa, perlu adanya Lembaga yang menangani sengketa pemilu bersifat independent dan final. Mengingat bahwa kasus sengketa pemilu yang masuk dalam MK lebih banyak dibandingkan perkara yang masuk dalam kewenangan lainnya.

Penelitian yang membahas tentang Lembaga Penyelesaian Sengketa Pemilu secara umum cukup banyak dilakukan oleh para peneliti terdahulu. Berdasarkan hasil penelusuran terhadap beberapa literatur yang telah dilakukan, maka setidaknya ditemukan beberapa literatur, baik berupa jurnal yang membahas mengenai permasalahan ini.

Ruslan Husein pada tahun 2018 dalam artikelnya yang berjudul Transformasi Bawaslu Menjadi Peradilan Khusus mempunyai pandangan alternatif tugas Bawaslu sebagai peradilan khusus, yaitu: (1). Badan Peradilan Khusus Pemilu yang berada di Bawah Mahkamah Agung. (2). Badan Peradilan Khusus Pemilu sebagai Badan Otonom. (3). Peradilan Khusus Pemilu yang bersifat semi peradilan. ${ }^{6}$

Dalam artikel lain pun memberikan gagasan yang hampir serupa dengan gagasan yang ditulis oleh Ruslan Husein yakni ${ }^{7}$ (1). Desain Pengadilan Khusus Pilkada adalah bersifat ad hoc (2). Berada dibawah Mahkamah Agung (3). Memiliki wewenang untuk menangani segala sengketa yang timbul dalam proses pilkada, mulai dari sengketa adminitrasi dan tindak pidana pilkada, hingga perselisihan hasil pilkada (4). Pelanggaran kode etik penyelenggaraan pilkada, akan tetap menjadi kewenangan dari DKPP (5). Bawaslu Provinsi dan Panwaslu Kabupaten/Kota sebagai penyidik dan sekaligus sebagai Penuntut Umum dalam perkara pidana pilkada. ${ }^{8}$

Selain dua artikel diatas ada pula artikel lain yang pada prinsipnya serupa dengan dua artikel diatas yakni memberikan gagasan yakn: (1). Pemilihan Kepala Daerah (Pilkada) telah diputus oleh Mahkamah Konstitusi

\footnotetext{
6 Ruslan Husen, "Transformasi Bawaslu Menjadi Peradilan Khusus Pemilu," Jurnal Adhyaksa Pemilu 4, no. 1 (2018). Hlm. 5

${ }^{7}$ Dian Agung Wicaksono and Ola Anisa Ayutama, "Inisiasi Pengadilan Khusus Pemilihan Kepada Daerah Dalam Menghadapi Keserentakan Pemilihan Gubernur, Bupati, Dan Walikota Di Indonesia," Jurnal Rechts Vinding 4, no. 1 (2015). Hlm. 176-177.

${ }^{8}$ Dian Agung Wicaksono and Ola Anisa Ayutama, "Inisiasi Pengadilan Khusus Pemilihan Kepada Daerah Dalam Menghadapi Keserentakan Pemilihan Gubernur, Bupati, Dan Walikota Di Indonesia," Jurnal Rechts Vinding 4, no. 1 (2015). Hlm. 176-177.
} 
melalui Putusan Nomor 97/PUU-XI/2013 bukan termasuk dalam rezim pemilihan umum. Sehingga diperlukan adanya pengadilan khusus yang diberikan kewenangan untuk mengadili sengketa hasil Pilkada (2). Salah satu usulan kewenangan untuk mengadili perselisihan hasil Pilkada dapat diberikan pada Pengadilan Tinggi Tata Usaha Negara dibawah Mahkamah Agung baik dengan mekanisme pengadilan ad hoc maupun Majelis Khusus Tata Usaha Pemilu yang sudah ada melalui Undang-Undang Nomor 7 Tahun 2017 tentang Pemilihan Umum (3).

Usulan lain untuk memberikan kewenangan kepada Bawaslu untuk menjadi lembaga yang mengadili sengketa hasil pilkada menjadi memungkinkan dengan peran Bawaslu sebagai lembaga quasi judicial. Sehingga dapat dikembangkan menjadi election court dalam perkembangan penanganan sengketa pilkada maupun pemilu dimasa depan (4). Gagasan lain adalah dengan menformat ulang dan mendifinisikan kembali Pilkada sebagai Pilkada serentak Nasional yang dilaksanakan lima tahun sekali secara serentak diseluruh Nasional adalah ajang demokrasi (local) nasional yang dapat masuk rezim pemilihan umum.

Artikel tersebut menerangkan gagasan bahwa wacana lain pengalihan kewenangan sengketa Pilkada dari Mahkamah Agung ke Mahkamah Konstitusi dengan alasan bahwasannya Mahkamah Agung sudah terlalu overload dengan perkara yang ada, sehingga penambahan kewenangan yang ada di Mahkamah Agung akan membebani kinerja yudisial Mahkamah Agung dan tidak menjamin kepastian hukum bagi para pihak. ${ }^{9}$ Dalam hal ini sesuai dengan karya ilmiah yang ditulis ini yang menyatakan bahwa Bawaslu sebagai wadah tunggal pengadilan khusus sengketa dan mempunyai putusan yang bersifat final dan mengikat.

Secara umum jika dibandingkan dengan penelitian yang telah ada, yaitu pada temuan kajian ini yang memfokuskan pada (1). Upaya menjadikan Bawaslu sebagai wadah tunggal sebagai pengadilan khusus sengketa pemilu layaknya Mahkamah Konstitusi jadi berdiri sendiri bukan dibawah Mahkamah

${ }^{9}$ Dian Agung Wicaksono and Ola Anisa Ayutama, "Inisiasi Pengadilan Khusus Pemilihan Kepada Daerah Dalam Menghadapi Keserentakan Pemilihan Gubernur, Bupati, Dan Walikota Di Indonesia,". Hlm. 206 
Agung (2). Obyek sengketa pengadilan khusus tersebut berkenaan dengan syarat formil maupun matriil terkait pemilu (3). Putusan bersifat final dan mengikat, jadi tidak ada upaya hukum lain terhadap putusan ini sama halnya produk putusan yang dihasilkan oleh Mahkamah Konstitusi.

Apabila dibandingkan dengan artikel yang sudah ada peradilan tersebut ada dibawah Mahkamah Agung dan membagi peradilan-peradilan dibawahnya tingkat pertama dan tingkat banding, maka sifat putusan tersebut masih dapat dilakukan upaya hukum lain. Sehingga menambah beban dan kewenangan Mahkamah Agung sebagai Pengadilan Tingkat pertama dan Terakhir dalam memutus perkara.

\section{Rumusan Masalah}

Berdasarkan pendahuluan yang dipaparkan, maka permasalahan yang dirumuskan dalam tulisan ini adalah bagaimanakah lembaga penyelesaian sengketa pemilu yang ideal di Indonesia.

\section{Tujuan Penelitian}

Tujuan penelitian yakni untuk mengkaji dan menganalisis lembaga penyelesaian sengketa pemilu yang ideal di Indonesia.

\section{Metode Penelitian}

Dalam melakukan penelitian ini, tipe penelitian yang digunakan adalah penelitian hukum (legal research) yaitu suatu proses untuk menemukan aturan hukum, prinsip-prinsip hukum maupun doktrin-doktrin hukum agar dapat menjawab permasalahan hukum yang sedang dihadapi. ${ }^{10}$

Pendekatan yang digunakan dalam penelitian ini yaitu, pendekatan perundang-undangan adalah pendekatan dengan menggunakan legislasi dan regulasi yang berkaitan dengan isu hukum yang sedang dibahas. ${ }^{11}$ Dengan pendekataan ini maka dapat dilakukan dengan menelaah aturan hukum yang ada yakni Undang-Undang Dasar Tahun 1945 sebagai dasar tertinggi sumber

\footnotetext{
${ }^{10}$ Peter Mahmud Marzuki, Penelitian Hukum (Edisi Revisi) (Jakarta: Kencana Prenada Media Group, 2005), Hlm. 29.

${ }^{11}$ Peter Mahmud Marzuki, Penelitian Hukum (Edisi Revisi), Hlm.133
} 
hukum dan dikaitkan dengan aturan-aturan yang ada dibawahnya untuk menjawab rumusan masalah.

Kemudian pendekatan konseptual adalah pendekatan dengan menggunakan prinsip-prinsip hukum yang dikemukakan dalam pandanganpandangan sarjana maupun doktrin-doktrin hukum. Pendekatan konseptual digunakan apabila belum ada atau tidak aturan hukum yang dapat digunakan untuk masalah yang dihadapi. Meskipun tidak secara eksplisit dapat ditemukan dalam peraturan perundang-undangan. Konsep hukum dapat ditemukan didalamnya, sehingga untuk mengidentifikasi prinsip tersebut terlebih dahulu memahami konsep-konsep tersebut melalui pandanganpandangan dan doktrin. ${ }^{12}$ Pendekatan ini menelaah konsep yang sudah diaplikasikan oleh negara lain dengan memililah konsep tersebut untuk dapat diterapkan pada sistem negara Indonesia. Konsep yang diterapkan tersebut ialah Negara Brazil dan Thailand sebab apabila dilihat dari kultur dan kebutuhan untuk sistem di Indonesia kedua sistem tersebut lebih tepat untuk diterapkan. Konsep-konsep tersebut dalam karya ilmiah ini diambil dari dokumen-dokumen resmi, publikasi tentang hukum meliputi buku-buku teks, kamus-kamus hukum, jurnal-jurnal hukum, dan komentar atas putusan pengadilan.

Selanjutnya adalah pendekatan kasus yang dilakukan dengan menelaah kasus-kasus dengan isu yang sudah ada untuk menjawab rumusan masalah. ${ }^{13}$ Pendekatan kasus tersebut diambil dari kasus-kasus yang serupa yang pernah terjadi di Indonesia. Pendekatan kasus ini diambil dari Putusan Pengadilan Mahkamah Konstitusi Nomor 97/PUU-XI/2013 dihubungkan dengan jurnaljurnal hukum yang relevan untuk menjawab rumusan masalah.

Bahan hukum yang digunakan dalam penelitian ini, yaitu Bahan hukum primer, merupakan bahan hukum yang bersifat autoritatif artinya mempunyai otoritas yang terdiri dari perundang-undangan, catatan resmi atau risalah dalam perbuatan perundang-undangan dan putusan-putusan hakim. ${ }^{14}$

\footnotetext{
12 Peter Mahmud Marzuki, Hlm. 177-178.

${ }^{13}$ Peter Mahmud Marzuki, Hlm. 94.

${ }^{14}$ Peter Mahmud Marzuki. Hlm. 181.
} 
Penelitian Hukum ini menggunakan bahan hukum dari peraturan perundangundangan terkait, yaitu sebagai berikut :

4.1. Undang-Undang Dasar Negara Republik Indonesia Tahun $1945^{15}$;

4.2. Undang-Undang Nomor 7 tahun 2017 tentang Pemilihan Umum (Lembaran Negara Republik Indoneisa Tahun 2017 Nomor 182 dan Tambahan Lembaran Negara Republik Indonesia Nomor 6109) ${ }^{16}$;

4.3. Undang - Undang Nomor 22 Tahun 2007 tentang Penyelenggara Pemilu (Lembaran Negara Republik Indoneisa Tahun 2007 Nomor 59 Lembaran Negara Republik Indonesia Nomor 4721) ${ }^{17}$;

4.4. Undang-Undang Nomor 8 Tahun 2015 Tentang Perubahan Atas Undang-Undang Nomor 1 Tahun 2015 Tentang Penetapan Peraturan Pemerintah Pengganti Undang-Undang Nomor 1 Tahun 2014 Tentang Pemilihan Gubernur, Bupati, Dan Walikota Menjadi Undang-Undang (Lembaran Negara Republik Indonesia Tahun 2015 Nomor 57 Lembaran Negara Republik Indonesia Nomor $5678)^{18}$

4.5. Undang-Undang Nomor 24 Tahun 2003 tentang Mahkamah Konstitusi (Lembaran Negara Republik Indonesia Tahun 2003 Nomor 98 Lembaran Negara Republik Indoneisa Nomor 4316) ${ }^{19}$;

4.6. Putusan Mahkamah Konstitusi Nomor 97/PUU-XI/2013;

4.7. Peraturan Badan Pengawas Pemilu Nomor 18 Tahun 2018 Tentang Perubahan Atas Peraturan Badan Pengawas Pemilu Nomor 18 Tahun 2017 Tentang Tata Cara Penyelesaian Sengketa Pemilihan Umum.

\footnotetext{
${ }^{15}$ Undang-Undang Dasar Negara Republik Indonesia Tahun 1945.

${ }^{16}$ Undang-Undang Nomor 7 Tahun 2017 Tentang Pemilihan Umum (Lembaran Negara Republik Indoneisa Tahun 2017 Nomor 182 Dan Tambahan Lembaran Negara Republik Indonesia Nomor 6109).

${ }^{17}$ Undang-Undang Nomor 22 Tahun 2007 Tentang Penyelenggara Pemilu (Lembaran Negara Republik Indonesia Tahun 2007 Nomor 59 Lembaran Negara Republik Indonesia Nomor 4721).

${ }^{18}$ Undang-Undang Nomor 8 Tahun 2015 Tentang Perubahan Atas Undang-Undang Nomor 1 Tahun 2015 Tentang Penetapan Peraturan Pemerintah Pengganti Undang-Undang Nomor 1 Tahun 2014 Tentang Pemilihan Gubernur, Bupati, Dan Walikota Menjadi Undang-Undang (Lembaran Negara Republik Indonesia Nomor 5678.

${ }^{19}$ Undang-Undang Nomor 24 Tahun 2003 Tentang Mahkamah Konstitusi (Lembaran Negara Republik Indonesia Tahun 2003 Nomor 98 Lembaran Negara Republik Indoneisa Nomor 4316).
} 
Kemudian bahan hukum sekunder, berupa semua publikasi tentang hukum yang bukan merupakan dokumen-dokumen resmi, publikasi tentang hukum meliputi buku-buku teks, kamus-kamus hukum, jurnal-jurnal hukum, dan komentar atas putusan pengadilan. Dalam hal ini digunakan bahan hukum sekunder berupa jurnal-jurnal hukum, hasil-hasil penelitian hukum serta hasil karya dari kalangan hukum termasuk artikel-artikel hukum di internet yang berkaitan dengan isu hukum yang dibahas.

Dalam hal pengumpulan bahan hukum baik bahan hukum primer maupun bahan hukum sekunder metode yang digunakan adalah metode studi pustaka. Sumber bahan hukum yang tekait dikumpulkan kemudian diseleksi disesuaikan dengan isu hukum kemudian ditelaah dan disesuaikan. Bahanbahan hukum tersebut kemudian dikaitkan dengan ketentuan hukum yang berlaku untuk selanjutnya dilklasifikasi dan disusun secara sistematis dengan rumusan masalah agar dapat memudahkan dalam menjawab rumusan masalah.

Analisis bahan hukum dilakukan dengan cara melakukan pengelompokan berdasarkan rumusan masalah yang ada kemudian diklasifikasi dan disusun sesuai rumusan masalah agar dapat memudahkan dalam menjawab rumusan masalah yang ada.

\section{Hasil Penelitian dan Pembahasan}

\section{Lembaga Penyelesaian Sengketa Pemilu yang Ideal di Indonesia}

Pemilu merupakan salah satu elemen terpenting untuk merawat kedaulatan rakyat. Dalam demokrasi kedaulatan rakyat (people sovereignty) merupakan konsep tertinggi yang memastikan bahwa kekuasaan pemerintahan (the power of government, de macht van de overheid) harus dibatasi. Pembatasan kekuasaan pemerintah adalah fondasi dasar dari suatu negara demokrasi. Dalam Undang-Undang dasar 1945 Pasal 22E dijelaskan bahwa pemilihan umum dilaksanakan secara langsung, umum, bebas, dan adil setiap lima tahun sekali. Pemilihan umum diselenggarakan untuk memilih DPR, DPRD, DPD, Presiden dan Wakil Presiden. 
Pada tanggal 17 april 2019 Negara Republik Indonesia telah melakukan pesta demokrasi dengan memilih DPR, DPRD, DPD, Presiden dan Wakil Presiden, namun dalam penyelenggaraan pesta demokrasi tersebut tak luput dari maraknya dugaan pelanggaran pemilu. Menurut Komisioner Bawaslu Mochammad Afifuddin melalui keterangan tertulis Data temuan tertinggi yang diterima Bawaslu adalah Jawa Timur 3.002 temuan, Sulawesi Selatan 772 temuan, Jawa Barat 514 temuan, Sulawesi Tengah 475 temuan dan Jawa Tengah 399 temuan. Sebelumnya, Bawaslu mengumumkan sejumlah laporan dugaan pelanggaran yang masuk ke sistem mereka saat pemungutan suara. Bawaslu mendapat 121.993 laporan dari seluruh pengawas Pemilu di seluruh Indonesia pada saat pemungutan suara, 17 April 2019. ${ }^{20}$

Dalam Pasal 93 Undang-Undang Nomor 7 Tahun 2017 tentang Pemilihan Umum disebutkan bahwa Bawaslu bertugas melakukan pencagahan dan penindakan terhadap pelanggaran pemilu dan sengketa proses pemilu. Pasal 94 menjelaskan bahwa dalam melakukan pencegahan pelanggaran Pemilu dan pencegahan sengketa proses Pemilu sebagaimana dimaksud dalam Pasal 93 huruf b, Bawaslu bertugas:

5.1. Mengidentifikasi dan memetakan potensi kerawanan serta pelanggaran Pemilu.

5.2. Mengoordinasikan, menyupervisi, membimbing, memantau dan mengevaluasi Penyelenggaraan Pemilu.

5.3. Berkoordinasi dengan instansi pemerintah terkait.

5.4. Meningkatkan partisipasi masyarakat dalam pengawasan Pemilu.

Sengketa penyelesaian hasil pemilu yang berwenang untuk memutuskan sengketa tersebut adalah Mahkamah Konstitusi. Dalam Pasal 24C ayat (1) UUD 1945 dan Pasal 10 ayat (1) Undang-Undang Nomor 24 Tahun 2003 tentang Mahkamah Konstitusi sebagaimana telah diubah oleh Undang-Undang Nomor 8 Tahun 2011 tentang Perubahan Atas UndangUndang Nomor 24 Tahun 2003 tentang Mahkamah Konstitusi dan kemudian diubah kedua kalinya oleh Peraturan Pemerintah Pengganti Undang-Undang

\footnotetext{
${ }^{20}$ Amirullah, "Bawaslu: Laporan Dugaan Pelanggaran Pemilu Terbanyak Ada Di Jatim," dalam https://nasional.tempo.co/read/1198624/bawaslu-laporan-dugaan-pelanggaran-pemiluterbanyak-ada-di-jatim/full\&view=ok, Akses 27 April 2019.
} 
Nomor 1 Tahun 2013 tentang Perubahan Kedua atas Undang-Undang Nomor 24 Tahun 2003 tentang Mahkamah Konstitusi dan kemudian ditetapkan oleh Undang-Undang Nomor 4 Tahun 2014 tentang Penetapan Peraturan Pemerintah Pengganti Undang-Undang Nomor 1 Tahun 2013 tentang Perubahan Kedua Atas Undang- Undang Nomor 24 Tahun 2003 tentang Mahkamah Konstitusi Menjadi Undang-Undang mengatur mengenai kewenangan MK, yakni berwenang mengadili pada tingkat pertama dan terakhir yang putusannya bersifat final untuk:

5.1. Menguji Undang-Undang terhadap Undang-Undang Dasar Negara Republik Indonesia Tahun 1945.

5.2. Memutus sengketa kewenangan lembaga negara yang kewenangannya diberikan oleh Undang-Undang Dasar Negara Republik Indonesia Tahun 1945.

5.3. Memutus pembubaran partai politik.

5.4. Memutus perselisihan tentang hasil pemilihan umum. ${ }^{21}$

Pada tahun 2014 MK menerima 767 sengketa pemilu legislatif. 735 perkara diajukan oleh partai politik dan 32 perkara diajukan oleh calon anggota Dewan Perwakilan Daerah. ${ }^{22}$ Kemudian pada tahun 2019 MK menerima 470 sengketa perkara PHPU pada Pemilu 2019. Secara rinci, 215 permohonan PHPU diajukan di tingkat Pemilihan Legislatif (Pileg) DPRD Kabupaten/Kota, 110 di tingkat DPRD Provinsi, 71 di tingkat DPR, 11 di tingkat DPD, dan satu di tingkat Pilpres. Ada 62 permohonan PHPU yang tidak teridentifikasi tingkatan pemilunya. ${ }^{23}$

Banyaknya sengketa pemilu yang diterima MK, maka dengan ini perlunya Lembaga Peradilan Pemilu itu untuk dibentuk yang khusus untuk menangani sengketa yang berkaitan dengan pemilu itu. Terkait penyelesaian

\footnotetext{
${ }^{21}$ Hasanah Sovia, "Perbedaan Sengketa Proses Dengan Sengketa Hasil Pemilu," dalam https://www.hukumonline.com/klinik/detail/ulasan/lt5c4533ec18aa6/perbedaan-sengketa-prosesdengan-sengketa-hasil-pemilu, Akses 27 April 2019.

22 Febrian, "MK Terima 767 Sengketa Pemilu Legislatif 2014" dalam https://nasional.kompas.com/ $\mathrm{read} / 2014 / 05 / 16 / 1644242 /$ MK.Terima.767.Sengketa.Pemilu.Legislatif.2014, Akses 23 November 2018.

23 Dimas Jarot Bayu, "Jumlah Gugatan Sengketa Pemilu Tahun 2019 Turun 2 Kali Lipat Dibanding 2014 dalam https://katadata.co.id/berita/2019/05/26/jumlah-gugatan-sengketa-pemilu2019-turun-2-kali-lipat-dibanding-2014, Akses 27 Desember 2019.
} 
sengketa pemilu ini dapat dibentuk oleh Lembaga peradilan khusus atau Lembaga non peradilan yang khusus menangani sengketa pemilu. Lembaga peradilan khusus dapat diambil contoh negara yang menerapkan peradilan khusus ini.

Negara yang menerapkan peradilan khusus adalah Brazil. Brazil adalah negara Amerika Latin yang berpenduduk terbesar kedua sesudah Amerika Serikat. Sistem penanganan sengketa pemilu di Brasil termasuk sistem yang paling efektif di dunia. Hal ini terlihat melalui ketentuan-ketentuan yang diatur secara tegas, baik dalam Konstitusi dan Undang-Undang Pemilunya. Keanggotaan Superior Electoral Court (SEC), terdiri dari 7 (tujuh) hakim yang diangkat melalui pemilihan secara rahasia dan penunjukan oleh Presiden.

Dalam hal ini, SEC berkedudukan di ibukota negara dan memiliki yurisdiksi di seluruh wilayah negara Brazil. Ketua dan Wakil Ketua SEC dipilih dari hakim-hakim Mahkamah Agung Federal dan Corregidor Electoral-nya diantara para hakim pengadilan Tinggi. Untuk mempertahankan karakter non-politis pengadilan pemilu, para hakim menjabat selama jangka waktu dua tahun dan tidak dapat menjabat lebih dari dua periode berturut-turut. Sejak dibentuk pada tahun 1932, SEC memiliki wewenang yang luas, mencakup keseluruhan aspek pemilu dan partai politik.

Sebagai Lembaga tertinggi dalam pengadilan pemilu di Brazil, kewenangannya antara lain meliputi pengesahan pendaftaran partai politik serta calon presiden dan wakil presiden, menangani konflik yurisdiksi antara pengadilan pemilu daerah, menangani perselisihan hasil akhir pemilu, menerima pengajuan banding dari pengadilan pemilihan daerah, mengesahkan pembagian negara menjadi daerah daerah pemilihan, menjawab pertanyaan dari partai politik yang berkaitan dengan masalah masalah pemilu, mengesahkan perhitungan suara, serta mengambil tindakan-tindakan lainnya yang dianggap perlu untuk melaksanakan Undang-Undang pemilu. ${ }^{24}$

\footnotetext{
${ }^{24}$ Bisariyadi et al., "Komparasi Mekanisme Penyelesaian Sengketa Pemilu Di Beberapa Negara Penganut Paham Demokrasi Konstitusional," Jurnal Konstitusi 9, no. 3 (2012). Hlm. 53162.
} 
Negara yang menggunakan sistem penyelesaian sengketa pemilu melalui Lembaga non peradilan. Salah satunya adalah negara Thailand. Thailand adalah negara dengan sistem pemerintahan monarki konstitusional. Dengan mengadopsi demokrasi dalam sistem pemerintahannya, Raja diposisikan sebagai kepala negara yang melaksanakan kekuasaan legislatifnya melalui parlemen, kekuasaan eksekutif melalui kabinet, dan kekuasaan yudisial melalui pengadilan.

Dalam konteks penangangan sengketa pemilu, Komisi Pemilu Thailand (Election Commission of Thailand, (ECT) diberi kewenangan oleh Konstitusi Thailand untuk menyelesaikan gugatan atau keberatan yang terjadi. Sistem penanganan keberatan di Thailand berbeda dengan negara-negara kebanyakan, karena justru ECT lah yang memiliki fungsi sebagai lembaga penanganan keberatan.

ECT diberikan hak oleh Undang-undang untuk menjalankan kewenangan yang luas untuk penyelidikan, penanganan dan menjatuhkan penalti yang berat untuk menghukum para pelanggar Undang-undang Pemilu berdasarkan titik berat yang dipertahankan terus menerus secara historis untuk mencegah jual beli suara.

Meskipun memiliki kewenangan khusus untuk menjadi wasit dan menangani kasus pelanggaran pemilu, ECT tidak dapat menangani kasus pidana dari pelaksanaan pemilu, oleh karena kasus pidana tetap diserahkan pada pengadilan.

Dasar dibentuknya Bawaslu sebagai peradilan khusus sengketa pemilu ialah :

5.1. Pasal 24 ayat (2) UUD 1945, yaitu : "kekuasaan kehakiman dilakukan oleh sebuah Mahkamah Agung dan badan peradilan yang berada dibawahnya dalam lingkungan peradilan umum, lingkungan peradilan agama, lingkungan peradilan milliter, dan lingkungan peradilan tata usaha negara, dan oleh lembaga Mahkamah Konstitusi”. kita bisa mencontoh pendirian Mahkamah Konstitusi yang didasari oleh adanya Mahkamah Konstitusi di Austria, serta pengalihan kewenangan terkait pengujian undang-undang dari 
Mahkamah Agung kepada Mahkamah Konstitusi.

5.2. Pasal 22E ayat (2) UUD 1945 menyatakan Pemilu diselenggarakan untuk memilih anggota Dewan Perwakilan Rakyat (DPR), Dewan Perwakilan Daerah (DPD), Presiden dan Wakil Presiden dan Dewan Perwakilan Rakyat Daerah (DPRD).

5.3. Pasal 157 ayat (1) Undang-Undang Nomor 8 Tahun 2015 Tentang Perubahan Atas Undang-Undang Nomor 1 Tahun 2015 Tentang Penetapan Peraturan Pemerintah Pengganti Undang-Undang Nomor 1 Tahun 2014 Tentang Pemilihan Gubernur, Bupati, Dan Walikota Menjadi Undang-Undang yang menyatakan bahwa “ Perkara perselisihan hasil Pemilihan diperiksa dan diadili oleh badan peradilan khusus".

5.4. Putusan Mahkamah Konstitusi Nomor 97/PUU-XI/2013 yang menyatakan bahwa "Mahkamah Konstitusi berwenang mengadili perselisihan hasil pemilihan umum kepala daerah selama belum ada Undang-Undang yang mengatur demikian. ${ }^{25}$

Prinsip-prinsip hukum yang dapat dijadikan landasan oleh Bawaslu sebagai peradilan khusus sengketa pemilu, yang diambil dari putusan-putusan perkara PHPU yang diputuskan oleh MK : ${ }^{26}$

\subsection{Prinsip Kebenaran Materiil Mengatasi Kebenaran Formil}

Tujuan peradilan adalah untuk menemukan kebenaran materiil sebagai dasar menegakkan keadilan substansif. Aturan hukum formal dan prosedural dibentuk untuk menjamin adanya kebenaran materiil dan tercapainya keadilan substansif. Karena itu, pada saat kebenaran materiil justru terhalangi oleh kebenaran formil. Hal ini dapat dilihat dari putusan-putusan PHPU yang mengungkap adanya pelanggaran-pelanggaran terhadap konstitusionalitas penyelenggaraan pemilu yang pasti mempengarui hasil pemilu. Selain itu juga dapat dilihat pada perkara pelanggaran asas jujur

25 Putusan Nomor 97/PUU-XI/2013 Tentang Pemerintah Daerah dan Kekuasaan Kehakiman, Hlm. 60.

${ }^{26}$ Janedjri M. Gaffar, Hukum Pemilu Dalam Yurisprudensi Mahkamah Konstitusi (Jakarta: Konstitusi Press (Konpress), 2013), Hlm. 204-206. 
dimana seseorang calon walaupun secara formal telah memenuhi syarat sebagai calon dan terpilih namun secara materiil ternyata tidak memenuhi maka calon tidak dipidana sehingga MK hanya menggugurkan keabsahan calon dan membatalakan hasil Pemilukada.

5.2. Prinsip Keputusan dalam Proses Demokrasi Dapat Dibatalkan Pengadlian.

Aturan Hukum dibuat untuk memastikan tujuan dan asas hukum dan demokrasi itu sendiri dapat terwujud. Konsekuensinya, proses demokrasi yang melanggar tujuan dan asas hukum dapat dibatalkan oleh putusan hukum, yaitu putusan pengadilan. Hal ini tercermin dalam putusan-putusan MK yang membatalkan KPU dan KPUD apabila terdapat pelanggaran konstitusionalitas penyelenggaraan Pemilu, baik terkait dengan calon, proses pemilihan, maupun karena penyelenggara Pemilu tidak melaksanakan putusan pengadilan.

\subsection{Prinsip Perlindungan Hak Konstitusional Warga Negara}

Pemilu adalah proses yang menjembatani warga negara dan negara. Pemilu diselenggarakan sebagai bentuk pengakuan hak warga negara terutama dibidang politik untuk dilindungi. Maka merupakan kewajiban pengadilan untuk melindungi dan mengembalikan hak konstitusional warga negara yang dilanggar. Hak konstitusional ini meliputi :

5.3.1 Hak Memilih (the rights to vote).

5.3.2 Hak untuk mencalonkan diri (the rights to be candidate).

5.3.3 Hak mengajukan calon (the rights to propose candidate).

5.3.4 Hak bebas dari ketakutan dalam menjalankan hak-hak tersebut (the freedom from fears).

5.4. Prinsip Memerhatikan Perkembangan Masyarakat

Memperhatikan dan mempertimbangkan perkembangan masyarakat dalam memutus perkara-perkara PHPU sehingga diharapkan sesuai dengan keadilan masyarakat serta dapat 
menyelesaikan permasalahan yang terjadi di masyarakat. Putusan yang memperhatikan perkembangan masyarakat dapat dilihat pada putusan penggunaan KTP dan Paspor, putusan sengketa internal calon, dan putusan MK terkait dengan tahapan Pemilukada di Aceh yang memberikan solusi hukum atas persoalan yang terjadi.

Berdasarkan paparan terkait model Lembaga yang digunakan dalam sengketa pemilu. Lembaga peradilan ataukah Lembaga non peradilan yang sesuai dengan penerapan hukum di Indonesia untuk mengganti MK sebagai Lembaga yang menyelesaikan sengketa pemilu. Lembaga yang sesuai adalah Lembaga peradilan. Seperti di negara Brazil yang menggunakan Superior Electoral Court. Jadi Bawaslu ini dibentuk sebagai Lembaga peradilan yang menggantikan MK untuk menyelesaikan sengketa pemilu.

\section{Kesimpulan}

Bawaslu sebagai Lembaga independent yang berfungsi sebagai pengawas pemilu ini bisa dijadikan sebagai Lembaga peradilan khusus untuk menangani sengketa pemilu. Bawaslu bisa mengambil contoh di negara Brazil Negara yang menerapkan peradilan khusus. Sistem penanganan sengketa pemilu di Brasil termasuk sistem yang paling efektif di dunia. Hal ini terlihat melalui ketentuan-ketentuan yang diatur secara tegas, baik dalam Konstitusi dan Undang-Undang Pemilunya. Keanggotaan Superior Electoral Court (SEC), terdiri dari 7 (tujuh) hakim yang diangkat melalui pemilihan secara rahasia dan penunjukan oleh Presiden. Oleh sebab itu Indonesia dapat mengambil contoh penerapan dari negara brazil sebagai Lembaga Penyelesaian Sengketa yang ideal. 


\section{DAFTAR PUSTAKA}

\section{Buku}

Amirullah. "Bawaslu: Laporan Dugaan Pelanggaran Pemilu Terbanyak Ada Di Jatim," n.d.

DIY, KPU. "Sejarah Pemilu Di Indonesia,” n.d.

Febrian. "MK Terima 767 Sengketa Pemilu Legislatif 2014,” n.d.

Gaffar, Janedjri M. Hukum Pemilu Dalam Yurisprudensi Mahkamah Konstitusi. Jakarta: Konstitusi Press (Konpress), 2013.

Husen, Ruslan. "Transformasi Bawaslu Menjadi Peradilan Khusus Pemilu." Jurnal Adhyaksa Pemilu 4, no. 1 (2018).

Marzuki, Peter Mahmud. Penelitian Hukum (Edisi Revisi). Jakarta: Kencana Prenada Media Group, 2005.

Putusan Nomor 97/PUU-XI/2013 tentang Pemerintah Daerah dan Kekuasaan Kehakiman (n.d.).

Sinaga, Kariaman. Efektitas Regulasi Dan Perannya Dalam Penyelenggaraan Pemilukada: Dialektika Hukum Dan Etika Pemilukada Serentak. Jakarta: Dewan Kehormatan Penyelenggara Pemilu RI, 2016.

Sovia, Hasanah. "Perbedaan Sengketa Proses Dengan Sengketa Hasil Pemilu," n.d.

\section{Artikel Jurnal}

Bisariyadi, Anna Triningsih, Meyrinda Rahmawaty H., and Alia Harumdani W. "Komparasi Mekanisme Penyelesaian Sengketa Pemilu Di Beberapa Negara Penganut Paham Demokrasi Konstitusional." Jurnal Konstitusi 9, no. 3 (2012).

Wicaksono, Dian Agung, and Ola Anisa Ayutama. "Inisiasi Pengadilan Khusus Pemilihan Kepada Daerah Dalam Menghadapi Keserentakan Pemilihan Gubernur, Bupati, Dan Walikota Di Indonesia.” Jurnal Rechts Vinding 4, no. 1 (2015). 


\section{Peraturan Perundang-undangan}

Undang-Undang Dasar Negara Republik Indonesia Tahun 1945 (n.d.).

Undang-Undang Nomor 22 Tahun 2007 tentang Penyelenggara Pemilu

(Lembaran Negara Republik Indoneisa Tahun 2007 Nomor 59

Lembaran Negara Republik Indonesia Nomor 4721) (n.d.).

Undang-Undang Nomor 24 Tahun 2003 tentang Mahkamah Konstitusi

(Lembaran Negara Republik Indonesia Tahun 2003 Nomor 98

Lembaran Negara Republik Indoneisa Nomor 4316) (n.d.).

Undang-Undang Nomor 7 tahun 2017 tentang Pemilihan Umum (Lembaran

Negara Republik Indoneisa Tahun 2017 Nomor 182 dan Tambahan

Lembaran Negara Republik Indonesia Nomor 6109) (n.d.).

Undang-Undang Nomor 8 Tahun 2015 Tentang Perubahan Atas Undang-

Undang Nomor 1 Tahun 2015 Tentang Penetapan Peraturan

Pemerintah Pengganti Undang-Undang Nomor 1 Tahun 2014

Tentang Pemilihan Gubernur, Bupati, Dan Walikota Menjadi

Undang-Undang (Lembaran Neg (n.d.).

\section{Media Online}

Amirullah. "Bawaslu: Laporan Dugaan Pelanggaran Pemilu Terbanyak Ada Di Jatim.” dalam https://nasional.tempo.co/read/1198624/bawaslulaporan-dugaan-pelang garan-pemilu-terbanyak-ada-di-jatim/full\&view=ok, Akses 27 April 2019.

Bawaslu. "Profil Bawaslu RI." dalam https:/www.bawaslu.go.id/id/profil, Akses 9 April 2019.

DIY, KPU. "Sejarah Pemilu Di Indonesia." dalam https://diy.kpu.go.id/web/2016/12/

22/sejarah-pemilu-di-indonesia/, Akses 23 November 2018.

Febrian. "MK Terima 767 Sengketa Pemilu Legislatif 2014." dalam https://nasional.

kompas.com/read/2014/05/16/1644242/MK.Terima.767.Sengketa.Pe milu.Legislatif.2014, Akses 23 November 2018. 
Dimas Jarot Bayu, “Jumlah Gugatan Sengketa Pemilu Tahun 2019 Turun 2 Kali Lipat Dibanding 2014 dalam https://katadata.co.id/berita/2019/05/26/jumlah-gugatan-sengketapemilu-2019-turun-2-kali-lipat-dibanding-2014, Akses 27 Desember 2019.

Jata, Ayu Pramesti Tri. "Perbedaan Peradilan Dengan Pengadilan." dalam https://www.hukumonline.com/klinik/detail/ulasan/lt548d38322cdf2/ perbedaan-peradilan-dengan-pengadilan, Akses 10 April 2019.

Sovia, Hasanah. "Perbedaan Sengketa Proses Dengan Sengketa Hasil Pemilu." dalam https://www.hukumonline.com/klinik/detail/ulasan/lt5c4533ec18aa6/ perbedaan-sengketa-proses-dengan-sengketa-hasil-pemilu, Akses 27 April 2019. 